An Action Research:The effect of using the Unified

Question as a Teaching Technique for Improving

Saudi Female Student Teachers' Knowledge

Retention and their academic performance at

Princess Nourahbint Abdulrahman University

Reem A. Aldegether

College of Education,

Princess NourhabintAbdulrahman University

Saudi Arabia 
An Action Research:The effect of using the Unified Question as a Teaching Technique for Improving Saudi Female Student Teachers' Knowledge Retention and their academic performance at Princess Nourahbint

\section{Abdulrahman University}

أثر استخام اسلوب السؤال الموحد كأسلوب تدريس في استبقاء المعرفة وتحسين

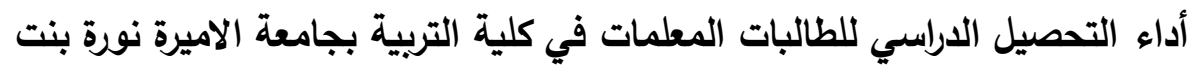

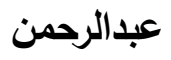

$$
\text { ريم احمد الدغيثر }
$$

قسم المناهج وطرق التدريس كلية التربية جامعة الأميرة نورة بنت عبد الرحمن

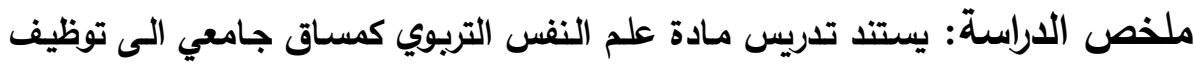

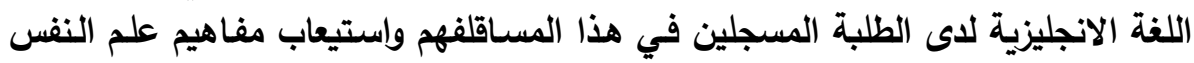

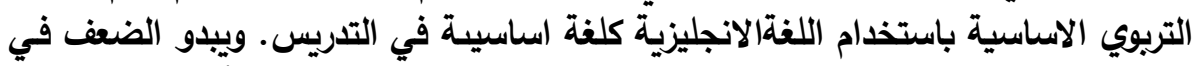

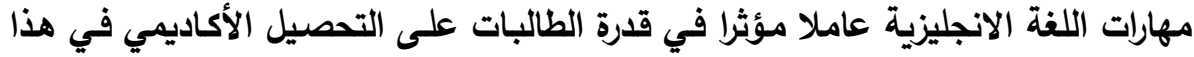

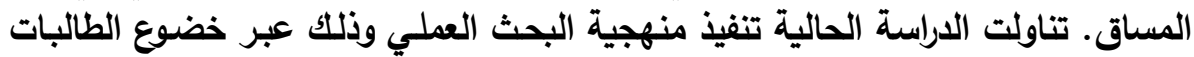

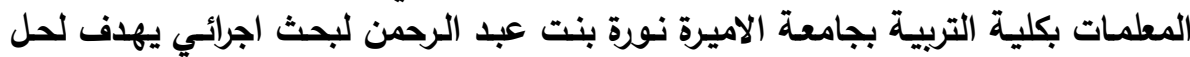

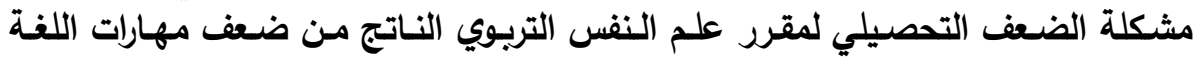

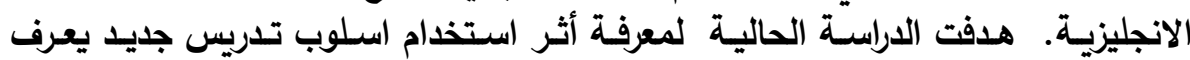

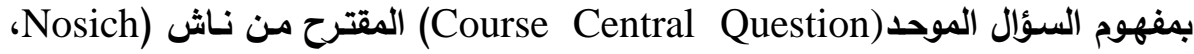

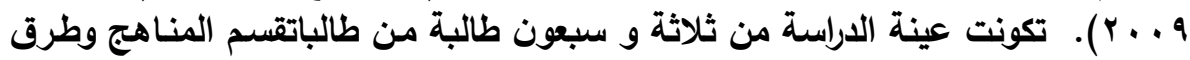

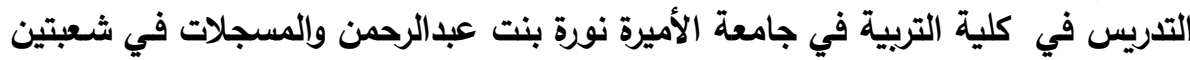

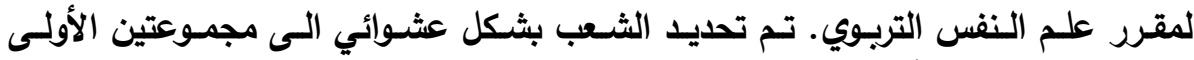

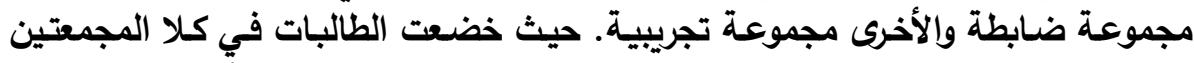

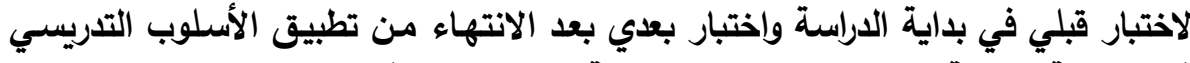

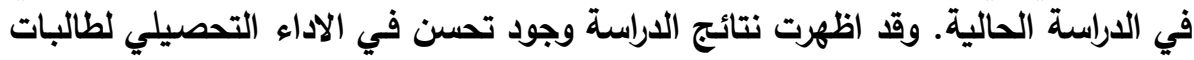

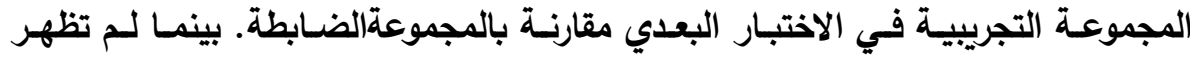

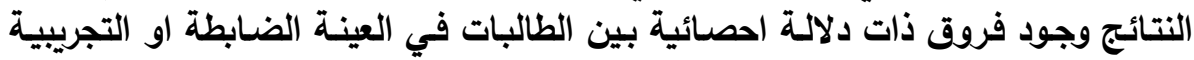

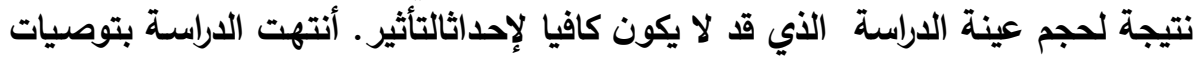

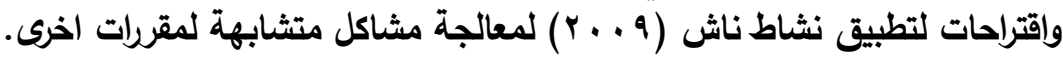
كلمات مفتاحية: التفكير الناقد -المفاهيم القوية والاساسية -السؤالالموحد-الطالبات المعلمات 


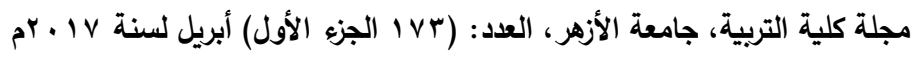

An Action Research:The effect of using the Unifined Question as a Teaching Technique for Improving Saudi Female Student Teachers' Knowledge Retention and their academic performance at Princess Nourah bint Abdulrahman University

Abstract:Using the English lanugae as a mean for teaching an educational psychology course brough to light problems related to students' poor English language skills in Content and Language Integrated Learning (CLIL) courses that affected their undestading of the course materials. Female Saudi student teachers have been exposed to a new teaching technique to improve student teacher content retention and academic performance. No research has been done that investigated using the central question of a course suggested by Nosich (2009) as a teaching strategy. Results are taken from one semester long application of the model proposed by Nosich on two groups. A sample of 73 students who are randomly selected participated in the study. Control and experimental design methods were utilized to investigate the influence of the current model. The instrument used to measure the outcome of the model was an achievement test design by the researcher. The achevement test was adminstred at the beginning and at the end of the semester. The results indicated positive influence the model has on students' content retention shown on the improvement of achievement test scores. The implication of the possible way to implementation method is explored. Suggestions for teacher education is provided.

Key words: Critical thinking-fundamental and powerful conceptcentral question of a course- student teacher

An Action Research:The effect of using the Unifined Question as a Teaching Technique for Improving Saudi

Female Student Teachers' Knowledge Retention and their academic performance at

Princess Nourah bint Abdulrahman University

\section{I.Introduction}

Extensive research has been conducted on the effect of different teaching methods on students' academic performance in various areas and disciplines (e.g. Becker, 2005; Lewis, Perry \& Murata, 2006;Aiken, 2007; Harrison, 2008; Oche, 2012; Ilgan, 2013; Osman\&Vebrianto, 2013; Burns, Henry \&Lindauer, 2015).

$$
\text { -V^०- }
$$


Explorations of the different types of teaching methods provided teachers with different avenues to differentiate their teaching methods to accommodate differences and overcome obstacles that might hinder students from learning. These studies have provided teacher educators and faculty from different disciplines with different models and strategies to improve their teaching from content based instruction to cognitive instruction that help students engage more thoughtfully when dealing with the content. Yet, the research on effective teaching methods continues to generate interest in identifying the best methods to maximize students' learning (Hightower et al., 2011).

Content and Language Integrated Learning (CLIL) as an example, is an educational practice that focuses on using a foreign language as a mean of instruction (Puffer, 2007). The focus in CLIL is the content, not the language (Lantolf\&Poehner, 2009). The purpose of CLIL is to cover the course curriculum using a foreign language. For example, usingthe English languageto teach a psychology course with an Arabic speaking class. Most CLIL research reported that the CLIL outcomes in term of content is positive. That is CLIL students were able to possess the content as their peer who taught the same subject in their L1 language (Daton-Puffer, 2007). Issues however, related to motivation, student engagement, and language production remain subjects controversial and needed further investigations (Bruton, 2011). In case of Saudi Arabia, no research has been found that address content and language integrated learning theory in Saudi Arabian context or any other Arabic context.

\section{The Central Question of a Course}

Nosich (2009) defines the central question of the course as "a unifying question that everything in the course fits into that question" $(p, 111)$. It helps understand every idea in the course by understanding how all parts of a discipline fit together. The purpose of the central question is to stimulate students' thinking throughout the course. The goal is, Nosich (2009) argued, is to develop a habit of thinking within the logic of the course to connect and relate a new idea to the old ones and connect them back to the course central question. Advocates of critical thinking argue that thinking within the logic of the course helps students who have trouble grasping the course purpose and identifying the connection. According to Nosich (2009), the major obstacles 
students face with challenging courses are not knowing where to begin and what questions to ask. He also asserts that the central question as a technique guides faculty member's to use key concepts of the course through focusing on the fundamental and the powerful concepts that unify the course purpose.

The concept of the central question of a course can only found to be directly related to Paul-Elder (2006) model of critical thinking. The Paul-Elder (2006) model of critical thinking emphasizes the importance of reflection on thinking through, asking questions, and connecting concepts. The Paul-Elder approach to critical thinking is based on eight elements of reasoning. Each of these elements helps students in answering questions related to a topic through identifying its purpose and viewpoints, until reaching a conclusion. These elements are: purpose, the question at issue, concepts, point of view, information, interpretation and inference, assumptions, and conclusion. The elements help students grasp the logic of the course. Each of these elements is identified by asking detailed questions that help answer them. For example, when a student thinks within a topic, he/she ask a question about the purpose: what purpose am I trying to achieve? What are my main questions? The Paul-Elder model of critical thinking is all about asking questions stimulated by the eight elements (Hhomann, Grillo, 2014). The Paul Elder model of critical thinking generates various research in different disciplines which have proven their effectiveness in encouraging critical thinking and promote learning (e.g. Elder \& Paul, 1994 and 1997; Thomas, 1999; Fink, 2003;Diago, 2006;Duron,Limbach\& Waugh, 2006; Hale, 2008; O'Hare \& McGuinness, 2009).

In the book,Learning to think thing through: A guide to critical thinking across curriculum, Gerald Nosich (2009) provides teachers as well as students with useful and easy exercises that guide them inhow to develop critical thinking skills using the Paul-Elder critical thinking model. The book provides detailed explanations on how to think within the logic of any discipline. It provides useful exercises that intended to help students work their way through any course. One of the concepts discussed in the book is how to use the central question. Nosich (2009) argues that every discipline has one central question that unifies all the course topics into one coherent idea. According to Nosich, the central question of a course "operates the same as a mission statement, it 
is a question you can ask yourself over and over. As your education and understanding increase, the depth in which you answer that question will increase" (Nosich, 2009, p, 114). The chapter provides different types of exercise on how to formulate the course question, and how to fit everything in the course into that question. Nosich provides examples of some of the central questions that can be generated from some discipline $(p, 133)$ :

> Educational Psychology: How does a student learn?

$>$ Composition: What is it to write and effective essay?

$>$ Philosophy: How can you make sense of your life and of the world around you?

$>$ Chemistry How are you and the world around you created by chemical?

Nosich book (2009) provided detailed explanations of the importance of understanding the logic of the course. Chapter 3 (pp, 89-138) of the book provided specific examples from different disciplines pointed out that the central question could be utilized by first, forming the central question of the course, then students should be asked to work on identifying the most fundamental and powerful concepts related to each topic in the course, and find out how this information fits together to answer the course's central question (p. 114). In the implementation section, detailed information about the technique will be provided.

Princess Nourah bint Abdulrahman University initiated a new program that offers a bachelor degree in elementary education for both Arabic and English teaching. The new program is supervised under the Department of Curriculum and Teaching in the School of Education. One of the required courses in the program is an educational psychology course. In the second year of the program implementation, the English language was assigned as the medium of instruction for the educational psychology course. The course was required for second year student teachers majoring in English Elementary Education. The purpose of the course was to provide student teachers with a full and rich understanding of human learning and a teacher's role in student learning. In any educational psychology course, theories that cover all aspects of human learning are presented. The course covered the theories' definitions, assumptions, facts, procedures, cases, objectives, and teaching methods with accordance with each theory. At the time of this study, the course had been taught in 
English for one semester. Student teachers in their second year of learning English language skills in addition to foundational courses related teaching and curriculum. It had been reported to the Department of Curriculum and Teaching student teachers struggle learning the course content due to their weak English language skills. The course had a complex academic vocabulary that demanded extra efforts from the students to understand the concepts and learn its terminology. Many student teachers taking the course struggled with both learning the language of the course and understanding the content itself. With increased frustration, many student teachers asked for English remediation classes to help them improve their language skills.

The instructor who taught the educational psychology course in English attributed the fall in performance to students' weak English language skills. During the class, students' reported to the instructor their struggle with the course vocabulary and the textbook's language. As the class materials became more challenging, students became more discouraged and unmotivated. It was extremely important to find a way to help students to benefit from the course. In addition to verifying the teaching methods and a lot of scaffolding, as a temporary solution, the instructor offered a brief explanation in the L1 (Arabic) to make sure that all students understood the concepts. In the following semester, the problem persisted with the next group of student teachers. Therefore, the instructor decided to support the next group with limited English proficiency. The instructor decided to use the technique the "central question" suggested by (Nosich, 2009). The central question of a course concept is based on an exercise that focuses on the fundamental and powerful concepts of the course (2009). This technique aims to formulate one central question that unifies every course item together. The present paper intended to report on the findings of an action research that used the "central question" of the course technique to improve the student teachers' course understanding and knowledge retention.

Limited studies, however, have been conducted that examine the methods that help students with Limited English Proficiency improve their content knowledge retention. In relation to that, the concept of the central question has not been tested yet as a teaching technique that can be used to improve content retention. This study is the first study in Saudi Arabia as well as in other countries that directly addresses this issue of using the 
Nosich model. This action research study did not intend to investigate issues related to content and language integrated learning methods in second/ foreign language nor measure its effectiveness on improving students thinking skills. Rather, to examine a teaching practice that best suites current students' circumstances to enhance their learning.

The present study did not intend to investigate issues in foreign language learning and teaching, but to report on a possible teaching technique that can be used to help students with limited English proficiency benefit from an educational psychology course assigned in a foreign language- English. The researcher used an exercise that helped students focus on important ideas and concepts in the course in order to answer the course central question.

\section{The Purpose of the Study}

The main purpose of the study was to investigate the influence of using the central question of the course as a technique in improving student teacher content retention in an educational psychology course. Specifically, the study asks: will students' content retention improve when they use the technique of the central question of the course?

Research questions:

- What are the mean achievement scores of student teachers taught using traditional (lecture methods) and Nosich Model (central question of the course)?

- What are the mean scores for the experimental group before and after using the teaching technique?

- Is there a significant difference in the mean achievement scores for both the experimental and the control groups?

\section{Method}

\section{A.Sample}

The study sample was73 prospective elementary student teachers enrolled in an educational psychology course at Princess Nourah bint Abdulrahman University. The 74 student teachers were divided into two sections. The two sections were randomly assigned to be part of the experimental or control group. Section 1 had 37 student teachers, and section 2 had 38 student teachers.

$$
-\vee 9 \cdot-
$$


The 74 student teachers were randomly assignedto be part of either the experimental or the control group. The two sections were taught by the same instructor.

\section{B. Experimental Design}

The central question exercise illustrated in the logic of the discipline chapter in Nosich book $(2009$, p. 113-116) guided this experimental study. At the beginning of the course, the student teachers in the experimental group were introduced to the central question exercise of the course. After explaining the logic and the purpose of using the central question after each theory, the class discussed the main purpose of the course and defined one question that the course is trying to answer. The question was: How do humans learn, and how can you teach your students in light of the proposed theory? The experimental class answered the central question of the course after each theory. The purpose was to connect the new concepts with the old ones and to the course central question. After answering the course question as class, the experimental class answered the central question in a written form. Each concept introduced was added to the previous theory concepts, and they explained how each concept contributed to human learning. Table 1 provides an example of the exercise.

Students in the control group received regular educational psychology course lectures that were based on lecturing and whole or group discussions. Both the experimental and the control group completed 8 weeks of instruction covering the same materials needed to answer the achievement test.

\section{Validity}

Pre- and post- achievement tests were used to measure the effect of the exercise on the students' content retention. The academic achievement test was administered at the beginning of the course and the post achievement test was given at the end of the semester to the same 73 students from teaching and curriculum department at Princess Nourah bint Abdulrahman University. The academic achievement test measured the basic concepts of educational psychology related to human learning, curriculum design, and instructional choices. The academic achievement test was reviewed by three faculty members from the department of teaching and curriculum who were prficient in 
both languages Arabic and English to check for content course coverage.

Figure 1

Sample of the achievement test

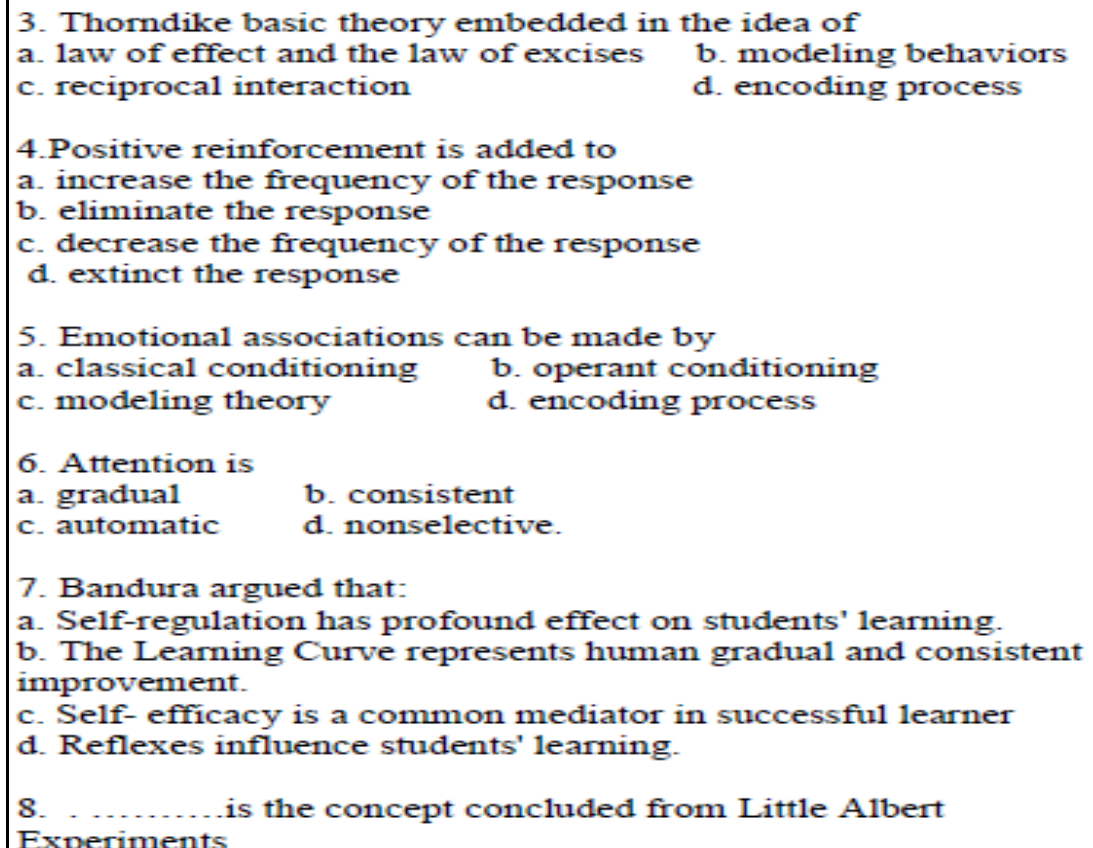

\section{Reliability}

The achievement test consisted of 20 multiple-choice items that measure content specific knowledge. The topics covered were behaviorism theories, social theories, constructivism theories, information processing theories, and cognitive theories. Short answer questions were also used to test the acquisition of these concepts. The estimation of the test reliability was calculated using

$$
-\vee 9 r-
$$


coefficient alpha and reported to be .73 of the total scale. The reliability result considered to be acceptable( Cohen, 1960).

\section{E. Study Implementation- The Model}

As discussed in the literature review section, the exercise on the central question of the course illustrated in the Nosich (2009) book, Learning to think things through: A guide to critical thinking across the curriculum, guided this current study. At the beginning of the course, the instructor illustrated how the course would be organized. During the first two weeks of the course, the instructor introduced the student teachers to the learning theories and their function. During these weeks, the instructor introduced the ideas of the central question of the course to the experimental group by discussing the purpose of the course and focusing on the idea of central question. The instructor explained how the main question of the course would be utilized throughout the semester for each new theory. The experimental class discussed the purpose of the learning theories and identified the central question of the course that was:How humans learn, and how you can teach your students in light of the proposed theory?

The subsequent weeks, each learning theory was introduced and discussed, student teachers identified the basic and fundamental concepts of the theory and connected these concepts to the central question of the course. The discussions followed and sought to answer the question: "how this theory contributes or helps to answer the central question?" and "how this question is important for my future profession?" The student teachers answered the questions in written form either in-group or individually and reported back to the whole class.

Organization of the exercise:

$>$ Participants identify the fundamental and powerful concepts

$>$ Review the central question of the course

$>$ Write the answer on the board depending on the target theory (behaviorism theory for example).

$>$ Break the central questions into sub questions trying to answer the question: Should (theory $x$ ) shape my educational practices (teaching)? Yes, HOW?

$>$ Write their answers

$>$ Report and discuss 
Figure 2

An Illustrative example of a student answering the central question

of the course

Using the fundamental and powerful concepts to think through the central question of educational psychology PSY 211

The central question is: How human learn, and how you can teach your students in Light of these theories.

If I had to describe how human learn in just a few words, I would use five fundamental and powerful concepts: behaviorism, constructivism, imitation and observation, and processing of information through encoding. I would say that behaviorism is concerned with how a pupil can behave in such way that he or she can do certain things. Behaviorists believe that learning occurs through stimulus, response, reinforcement, trial and error, exercise, repetition. Children learn more if they know the consequences of their action. Behaviorism stresses a great deal,about how parents and teachers are responsible for the things children/students learned. They are responsible forupbringingchildren by shaping their environment.

Therefore, the way psychology describes human learning is very different from the way I used to know before taking this course. Now, I understand the behaviors of my students and my kids. I used to think that only reinforcement guarantee learning and reoccurrence of the desired behaviors. Now, I also know that having a peer model or figure that demonstrates a certain behavior, attitude, or action will produce learning.

I always thought that schools' environment and teachers are the only providers of knowledge of our kids. Learning from parents, peers, and even technology reinforces learning as Vygotsky suggested....... 


\section{Results}

A. Research Question 1\& 2 : What are the mean achievement scores of student teachers taught using traditional (lecture methods) and Nosich Model (central question of the course)? A pre- and post- test was used to measure the impact of using the Nosich Model on students' content retention. The majority of the participants in both groups have an average to low achievement usingboth methods. As shown in table 2 below, the mean scores after the implementation of the central question technique were slightly higher from the mean scores before the implementation for both groups and for the overall sample. In addition, scores fromtheexperimental group wereslightly higher than the scores from thecontrol group. The mean score for the experimental group after the intervention was $(M=12.43)$ and the mean score before was $(M=11.70)$. Whereas, the control group scored lower before $(M=10.50)$ thanafter $(M=11.4)$ the teaching in the achievement test These differences were further tested to examine if they were statistically significant or notusingt. test.

\section{Table 1}

Means and Standard Deviations for both experimental and control groups

\begin{tabular}{|c|c|c|c|c|}
\hline \multicolumn{5}{|c|}{ Descriptive Statistics } \\
\hline & Group & Mean & $\begin{array}{c}\text { Std. } \\
\text { Deviation }\end{array}$ & $\mathbf{N}$ \\
\hline \multicolumn{2}{|c|}{ scores before Control group } & 10.556 & 3.6757 & 36 \\
\hline & Experimental group & 11.730 & 2.7854 & 37 \\
\hline & $\begin{array}{l}\text { Overall pre-test score (for } \\
\text { both groups) }\end{array}$ & 11.151 & 3.2858 & 73 \\
\hline \multirow[t]{3}{*}{ scores after } & Control group & 11.472 & 2.3723 & 36 \\
\hline & Experimental group & 12.432 & 2.9678 & 37 \\
\hline & $\begin{array}{l}\text { Overall post-test score (for } \\
\text { both groups) }\end{array}$ & 11.959 & 2.7154 & 73 \\
\hline
\end{tabular}


B. Research Question 3: Is there a significant difference in the mean achievement scores for both the experimental and control groups? Differences between groups for both situations (pre- and post-) are examined using Independent-Samples t.test. The resultsare presented in table 3 below.Resultsshowed that there wereno significant differences between the two groups regarding pre-testsores $(t(71)=-1.541, p=0.128)$, as well as post-test intervention scores $(t(71)=-1.542, p=0.132)$.

Table 2

Independent Samples Test for pre-test and post-test scores for the groups

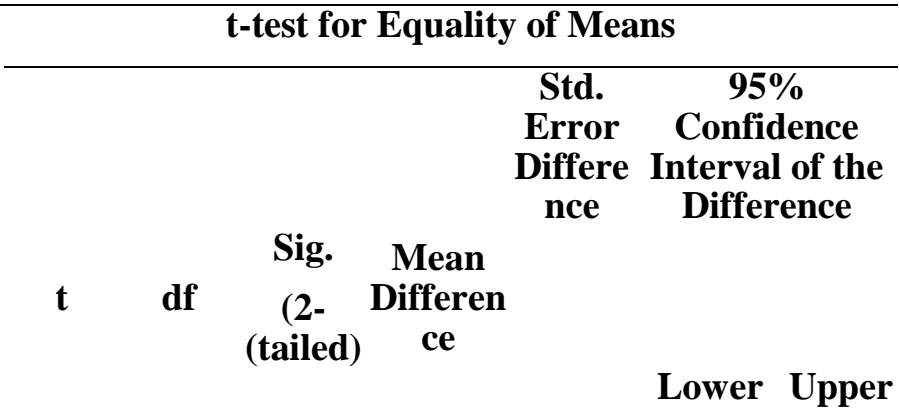

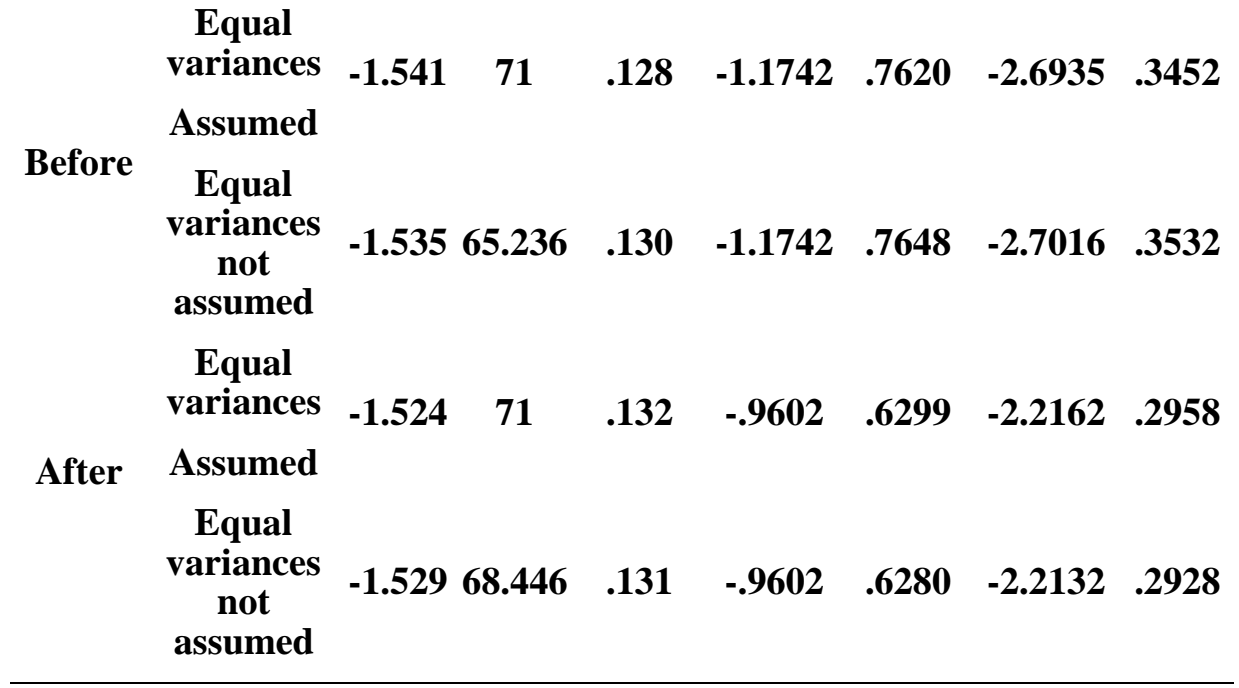


Moreover, the differences between pre-/post- situations for both groups wereexamined using Paired samples $t$.test. Results are presented in table 4 below, separately for experimental and control group.

Table 3

Paired Samples Statistics for the Control Group:

\begin{tabular}{llcccc}
\hline & Mean & N & $\begin{array}{c}\text { Std. } \\
\text { Deviation }\end{array}$ & $\begin{array}{c}\text { Std. Error } \\
\text { Mean }\end{array}$ \\
\hline Pair 1 & Pre- & $\mathbf{1 0 . 5 5 6}$ & 36 & $\mathbf{3 . 6 7 5 7}$ & $\mathbf{. 6 1 2 6}$ \\
& Post- & 11.472 & 36 & 2.3723 & .3954 \\
\hline
\end{tabular}

Table 4

Paired Samples Correlations for the Control Group

\begin{tabular}{lllll}
\hline & & N & $\begin{array}{l}\text { Correlati } \\
\text { on }\end{array}$ & Sig. \\
\hline $\begin{array}{l}\text { Pair } \\
1\end{array}$ & Pre \& Post & 36 & $\mathbf{. 6 4 4}$ & $\mathbf{. 0 0 0}$ \\
\hline
\end{tabular}

Scores for both experimental and control have significant and moderately high correlation $(r=0.644, p=0.000)$, which means that, in general, subjects with higher scores before intervention obtain higher scores after intervention, as well.

Table 5

Tests of Between-Subjects Effects for Control Group

\begin{tabular}{lccccc}
\hline & & Mean & N & $\begin{array}{c}\text { Std. } \\
\text { Deviation }\end{array}$ & $\begin{array}{c}\text { Std. Error } \\
\text { Mean }\end{array}$ \\
\hline \multirow{2}{*}{ Pair 1 } & Pre- & 11.730 & 37 & $\mathbf{2 . 7 8 5 4}$ & .4579 \\
& Post- & 12.432 & 37 & $\mathbf{2 . 9 6 7 8}$ & .4879 \\
\hline
\end{tabular}

Table6

Paired Samples Correlations for the Experimental Group 


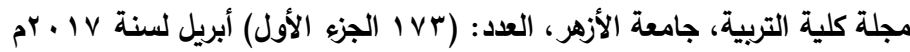

\begin{tabular}{llllll}
\hline & & & N & $\begin{array}{l}\text { Correlati } \\
\text { on }\end{array}$ & Sig. \\
\hline $\begin{array}{l}\text { Pair } \\
1\end{array}$ & $\begin{array}{l}\text { before } \\
\text { after }\end{array}$ & $\&$ & 37 & $\mathbf{. 6 0 9}$ & $\mathbf{. 0 0 0}$ \\
\hline
\end{tabular}

Scores in the two groups have a significant and moderately high correlation $(r=0.609, p=0.000)$, which means that, in general, subjects with higher scores before also obtained higher scores after intervention, as well. In order to test the group and the situation (intervention) differences simultaneously, $2 \times 2$ ANOVA was conducted Results are presented in tables 7and 18. The results show that the exercise used is a significant factor, but the interaction between intervention and group is not, which means that both groups obtained higher scores in the second testing. Test inter-subjects effect confirms that here are no significant difference between the two groups. So, slight differences obtained (experimental group have higher scores than the control), are, in fact, non-significant. Therefore, we can assume that non-significant results from the Paired-Samples $T$ test is a consequence of the small sample. Or we can conclude that intervention studies we should have a significant improvement as a result of our intervention and that, in fact, the intervention has a significant effect.

Table 7

Tests of Within-Subjects Effects for the Experimental Group:

\begin{tabular}{|c|c|c|c|c|c|}
\hline & Source & df & $\begin{array}{c}\text { Mean } \\
\text { Square }\end{array}$ & $\mathbf{F}$ & Sig. \\
\hline \multirow{4}{*}{ Situation } & $\begin{array}{l}\text { Sphericity } \\
\text { Assumed }\end{array}$ & 1 & 23.925 & 6.655 & .012 \\
\hline & $\begin{array}{l}\text { Greenhouse- } \\
\text { Geisser }\end{array}$ & 1.000 & 23.925 & 6.655 & .012 \\
\hline & Huynh-Feldt & 1.000 & 23.925 & 6.655 & .012 \\
\hline & Lower-bound & 1.000 & 23.925 & 6.655 & .012 \\
\hline \multirow{2}{*}{$\begin{array}{l}\text { Situation } \\
\text { group }\end{array}$} & $\begin{array}{l}\text { Sphericity } \\
\text { Assumed }\end{array}$ & 1 & .418 & .116 & .734 \\
\hline & $\begin{array}{l}\text { Greenhouse- } \\
\text { Geisser }\end{array}$ & 1.000 & .418 & .116 & .734 \\
\hline
\end{tabular}




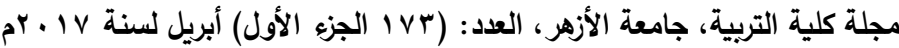

\begin{tabular}{|c|c|c|c|c|c|}
\hline \multicolumn{2}{|r|}{ Source } & df & $\begin{array}{l}\text { Mean } \\
\text { Square }\end{array}$ & $\mathbf{F}$ & Sig. \\
\hline \multirow{6}{*}{$\begin{array}{l}\text { Error(inter } \\
\text { vention) }\end{array}$} & Huynh-Feldt & 1.000 & .418 & .116 & .734 \\
\hline & Lower-bound & 1.000 & .418 & .116 & .734 \\
\hline & $\begin{array}{l}\text { Sphericity } \\
\text { Assumed }\end{array}$ & 71 & 3.595 & & \\
\hline & $\begin{array}{l}\text { Greenhouse- } \\
\text { Geisser }\end{array}$ & 71.000 & 3.595 & & \\
\hline & Huynh-Feldt & 71.000 & 3.595 & & \\
\hline & Lower-bound & 71.000 & 3.595 & & \\
\hline
\end{tabular}

Table 8

Tests of Between-Subjects Effects

\begin{tabular}{ccccccc}
\hline Source & $\begin{array}{c}\text { Type III } \\
\text { Sum of } \\
\text { Squares }\end{array}$ & df & $\begin{array}{c}\text { Mean } \\
\text { Square }\end{array}$ & F & Sig. \\
\hline Intercept & $\mathbf{1 9 4 6 4 . 6 3 1}$ & 1 & $\mathbf{1 9 4 6 4 . 6 3 1}$ & $\mathbf{1 3 6 6 . 9 5 3}$ & $\mathbf{. 0 0 0}$ \\
Group & 41.562 & 1 & 41.562 & 2.919 & .092 \\
Error & $\mathbf{1 0 1 1 . 0 0 0}$ & 71 & 14.239 & & \\
\hline
\end{tabular}

Figure3

Marginal Means

$-\vee 99-$ 


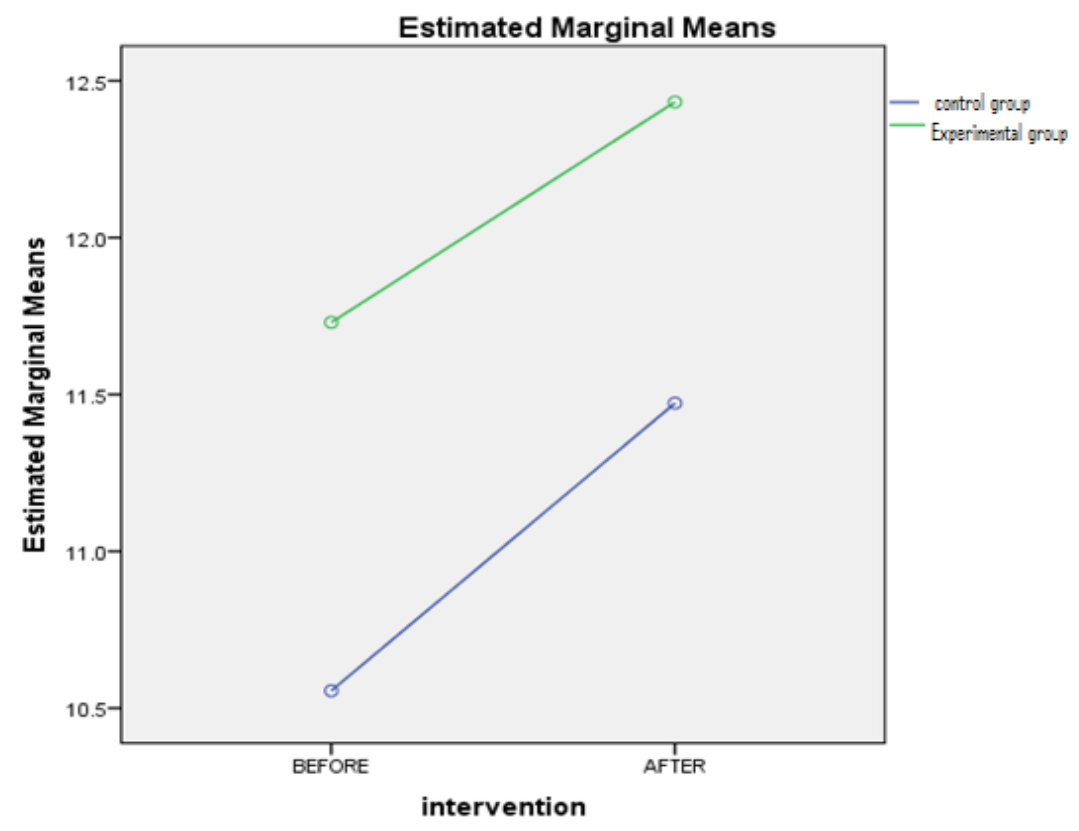

\section{Discussion and Conclusion}

The students' overall scores allow the researcher to conclude that the courses required in the English language should be given more attention in teacher education at Princess NourahbintAbdulrahman University. With more university courses required in the English language, it is necessary to test the effect of content integrated language on students' learning. The results generated from the achievement test showed that the section that used the central question scored slightly higher than the section that did not. Since this study is the first to be found that directly tested the central question as a teaching technique, the results cannot be confirmed with previous similar studies. Research studies on innovative teaching methods; however, have proven that verifying teaching methods to match students' needshelpenhancing learning (Ganyaupfu, 2013; Adunola, 2011; Collins, 2004; Damodharan\& Rengarajan, 1999). Furthermore, many studies investigated the importance of the logic of the course and have linked the logic of course with improving students' critical thinking and content retention (Pascarella\&Terenzini, 2005; Paul\& Elder, 2006, 2010; Read \&Klomrey, 2001). 
The purpose of the study was to help students with poor English skills benefit from an educational psychology course where English was the medium of instruction. The achievement test for the experimental group was higher than the section that did not incorporate the new teaching technique, but without significant differences. This may indicate that using the central question exercise might slightly improvestudents focus on the most important concepts of each theory and retain them. Nevertheless, it should be noted that many variables on using the central question asthe fundamental power concept andteaching technique needs to be further investigatedbeforeformingconclusions. The analysis of $t$.testrevealed that the differences between the two groups with before and after intervention were not significant.

\section{A. Recommendations}

The current study generated the following recommendations:

1. Teaching and curriculum department should test and adopt the cental question as teaching technique for other disciplines.

2. Coolaboration is recommended between faculty members from both Enlgish department and teaching and curriculum departmentto come up with sutible teaching methods for Content and Language Integrated Learning (CLIL) courses.

3. Create faculty group to share similar concerns and suggest soluations for similar problems related to Content and Language Integrated Learning (CLIL)

4. Test the effect of the central question technique with a larger sample.

5. The department of Curriculum and Teaching should have English placement test for students who are interested in majoring in English teaching for elementraryeducation to make sure that those students have the English language skills that will help them benefit from all coursese required in English.

\section{B. Conclusion}

The current study design has limitations as far as drawing conclusions. Thus, we cannot, for example, suggest that using the central question as a technique will improve students' content retention in this discipline or other disciplines unless tested. 
Furthermore, as indicted above, variables related to the language level, the sample size, the nature of the courses may affect the implementation of the exercise and eventually the results. Further research on the topic of using the central question as a technique should contribute to more understanding, as it appeared in this study to be a promising teaching technique.

Lastly, the department of Curriculum and Teaching should have an English placement test for students who are interested in majoring in English Teacher program to make sure that those students have the English language skills that are essential to benefit from these kinds of courses.

\section{Limitation of the study}

The study has the following limitations:

1. This study is limited to English Elementary female student teachers at Princess NourahbintAbdulrahman University.

2. Due to the nature of the research (An action research), the results of the study cannot be generalized.

\section{References}

Aiken, L., RL. (2007). Differential treatment of female and males in mathematics classes. Journal of Research in Mathematics Education, 12(3), 40-53.

Bruton, A. (2011). Is CLIL so beneficial, or just selective? Reevaluating some of the research. System, 39, pp, 523-532. 


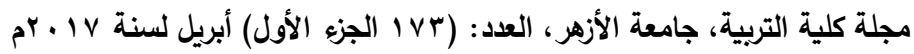

Burns, B., A., Henry, J., J., \&Lindauer, J., R. (2015). Wording together to foster candidate success on the endTPa. Journal ofInquiry\& Action in Education, 6 (2), 18-31.

Duron, R., Limbach, B., \& Waugh, W. (2006).Critical thinking framework for any discipline.International Journal of Teaching and Learning in Higher Education. 17 (2).160-166.

Elder, L., \& Paul, R. (1994). Critical thinking why we must transform our teaching. Journal of Development Education, 18 (1) 34-35.

Elder, L., \& Paul, R. (1997). Critical thinking: crucial distinction for questioning. Journal of Developmental Education, 21 (2), 34 .

Fink, L., Paul, R. (2003). A self- directed guide to designing courses for significant learning. San Francisco: Jossey-Bass.

Hale, E. (2008). A critical analysis of Richard Paul's substantive trans-discipinary conception of critical thinking.Union Institute \& University - Cincinnati, Ohio - October 2008

Harrison, C. (2008). Educations for tomorrow's school vocational teachers: overview. Digest No. 67.

Hhomann, J. W, Grillo, C. M. ( 2014). Using critical thinking rubric to increase academic performance. Journal of College Reading and Learning. 45:35-51.

ILgan, A. (2013). Predicting college student achievement in science courses. Journal of Baltic Science education, 12 (3), 322-336.

Lantolf, J., P., \&Poehner, M., E. (2010). Dynamic assessment in classroom: Vygotskian praxis for second language development. Language Teaching Research, 15 (1), 11-33.

Nosich, M., G. (2009). Learning to think things through: A guide to critical thinking across the curriculum. Upper Saddle River: Pearson Prentice.

O'Hare, L. O., \& McGuinness, C. (2009). Measuring critical thinking, intelligence, and academic performance in psychology undergraduates. The Irish Journal of Psychology, 30(3-4), 123-131. 
Oche, S., E. (2012).Assessing the Relative effectiveness of three teachingmethods in the measurement of student achievement in mathematics. Journal ofEmerging Trends in EducationalResearch and Policy. 3 (4), 497-486.

Osman, K., \&Vebrianto, R. (2013). Fostering science progress skills and improving achievement through the use of multiple media. Journal of Baltic Science Education, 12 (2), p, 91.

Thomas, P., E. (1999).Critical thinking instruction in selected greater Los Angeles area high schools. A dissertation Submitted to the School of Education and Behavioral Studies in partial fulfillment of the requirementsfor the degree Doctor of Education. 